\title{
EXTREME PRECIPITATION EVENTS AND ASSOCIATED RISK OF FAILURE IN HYDRAULIC PROJECTS IN THE STATE OF MATO GROSSO DO SUL, BRAZIL
}

\author{
EVENTOS EXTREMOS DE PRECIPITAÇÃO E O RISCO DE FALHA ASSOCIADO EM PROJETOS \\ HIDRÁULICOS NO ESTADO DE MATO GROSSO DO SUL, BRASIL
}

ANA CLARA COSTA OLIVEIRA | UFMS

ALESKA KAUFMANN ALMEIDA, M.SC. | UFMS

JOSÉ ANTONIO GUARIENTI | UFMS

CLEYLSE ANDREIA SOUZA LIMA, M.SC. |UFMS

LÍNIKA VICENTE FERREIRA DE ALMEIDA, M.SC.| UFMS

ROBERT SCHIAVETO DE SOUZA, Dr. |UFMS

ISABEL KAUFMANN DE ALMEIDA, Dra.| UFMS

\begin{abstract}
It is necessary to know the extreme precipitation occurrences in a region for satisfactory design of infrastructure projects. Tropical climate regions are characterized by heavy rainfall events during the summer, and, in recent years, as a result of climate change, such events are becoming recurrent. A theoretical probability distribution model is typically used to extrapolate extreme events for high return periods. This study verified if whether probability distribution models are efficient for estimation of extreme precipitation events for the normative recommended return period. Five cities in Mato Grosso do Sul State, in the Midwest region of Brazil, affected by disasters caused by heavy rainfall were adopted as a case study. The results illustrate that the recommendations of the return periods used for the design of hydraulic control structures are insufficient to avoid damage caused by precipitation events, thus lending a high breakdown risk to structures.
\end{abstract}

KEY WORDS: Maximum rainfall; Return period; Probabilistic analysis; Risk analysis; Lifetime structure; Probabilistic distribution model.

\begin{abstract}
RESUMO
É necessário conhecer as ocorrências extremas de precipitação em uma região para obtenção de projetos de infraestrutura satisfatórios. As regiões de clima tropical são caracterizadas por seus eventos de chuvas intensas durante o verão e, nos últimos anos, em decorrência das mudanças climáticas, esses eventos estão se tornando recorrentes. Um modelo de distribuição de probabilidade teórica é normalmente aplicado para extrapolar eventos extremos para altos períodos de retorno. Neste estudo, verificou-se se os modelos de distribuição de probabilidade são eficientes para estimar eventos extremos de precipitação para o período de retorno recomendado em normativas de dimensionamento de obras hidráulicas. Cinco cidades do estado de Mato Grosso do Sul, localizadas na região centro-oeste do Brasil, que foram afetadas por desastres causados por fortes chuvas foram adotadas como estudo de caso. Os resultados ilustram que as recomendações dos períodos de retorno utilizados para o dimensionamento das estruturas de controle hidráulico são insuficientes para evitar os danos causados por eventos de precipitação, gerando um alto risco de ruptura das estruturas.
\end{abstract}

PALAVRAS CHAVE: Precipitação máxima; Período de retorno; Análise probabilistica; Análise de risco; Vida útil da estrutura; Modelo de distribuição probabilística. 


\section{INTRODUCTION}

The Intergovernmental Panel on Climate Change (IPCC, 2012) indicated that extreme precipitation events have been increasing over many locations on the planet. According to Salas et al. (2013), some of the changes observed in the hydrological records may be due to the effects of natural climatic variability, particularly resulting from low-frequency components of climate variability such as the El Niño Southern Oscillation (ENSO). Kyoung et al. (2011) predicted that rainfall patterns will change significantly as a result of climate change. Hajani et al. (2017) affirmed that a possible increase in rainfall intensity driven by climate change might increase the risk of floods in many locations worldwide. Extreme events, when not predicted in the design of hydraulic control structures, can cause significant social and economic damage.

Many researchers (Rahmani et al., 2014; Yang et al., 2010; Koutsoyiannis, 2004) have conducted rainfall frequency distribution studies. According to Babar and Ramesh (2014), the stochastic behaviour of extreme events can be analyzed based on their probability distribution function. Thus, probability models such as the Gumbel, log-normal (LN), log Pearson type III (LP3), and normal models can be used for fitting the frequency distribution of precipitation and flood data. In these cases, the intensity of the precipitation is associated with the probability of it being equaled or exceeded. The inverse of this probability defines a range of rainfall occurrences of the same or greater magnitude, called the return period $(T)$, which is an average estimate of the time when an event is equaled or exceeded.

Muhammad et al. (2016) affirmed that return periods are useful in the field of hydrology to measure the severity of an event. In flood engineering practice, the return period has been defined as the average number of years to the first occurrence of a flood event of magnitude greater than a predefined design flood (Kite, 1977). The safety and durability of engineering projects are often associated with the return period adopted in the project. In the context of designing a hydraulic structure, return periods $\mathrm{T}$ are specified according to the type of structure to be designed. Design floods are determined from the frequency distribution of the corresponding flood data (Salas et al., 2013). Another important variable that can be obtained through frequency distribution studies is the risk. Risk is the probability that a certain project will fail during the lifetime of its use. According to Tingsanchali and Karim (2010), risk assessment, namely, identifying the possible impacts of any future flooding event, can help residents and authorities minimize economic and environmental losses.
The concepts of risk and uncertainty are commonly used for designing and evaluating flood-related hydraulic structures (Salas et al., 2013). A risk analysis should precede the sizing of projects that present a degree of complexity (such as unique works of art) before selecting the return period. In addition, hydraulic projects are generally designed by considering the minimum cost associated with an acceptable risk of failure. Therefore, the risk associated with damage caused by a hydrologic event higher than that predicted in the project, during the lifetime of its use, must be considered. This fact requires the prediction of hydrological quantities of significant magnitude, such as the maximum daily precipitation, which can cause flooding in a certain locality. According to Dave (2017), understanding the changes in extreme daily rainfall events is more important than realizing changes in the mean condition. The same author affirmed that 1-day extreme rainfall events occur not only in years of excess rainfall but also in years of drought. According to Jain and Kumar (2012), changes in rainfall from global warming require a review of the hydrologic design and management practices. Thus, it is necessary to develop studies that promote a better targeting of resources and technologies applied to disaster prevention.

Baptista et al. (2011) stated that, in Brazil, there are no specific regulations for the use of rainwater control devices in the cities; however, Brazilian legislation at federal, state, and municipal levels have legal instruments that can be used. Thus, the suggestions of manuals such as DNIT (2010), of the Departamento Nacional de Infraestrutura de Transportes (DNIT), and DAEE-CETESB (1986), of the Departamento de Águas e Energia Elétrica - Companhia de Tecnologia de Saneamento Ambiental (DAEE-CETESB), which present recommendations as to the return period to be adopted in the design of hydraulic projects, are based on a particular baseline.

This study focused on verifying if the probabilistic models of distribution, namely, Gumbel, LN, LP3 and Normal are efficient for an estimation of extreme events of precipitation for the recommended return period. This paper also discuss whether the methodology based on the return period that is used for the sizing of hydraulic projects in Brazil is adequate and safe for a tropical climate region. For this purpose, the cities of Amambaí, Iguatemi, Jardim, Naviraí, and Tacuru, located in the state of Mato Grosso do Sul, Brazil, which were affected by heavy rainfall and were declared as disaster area for a 180-day period in 2015, were adopted as a case study. 


\section{METHODOLOGY}

\subsection{Study area}

The study area (Fig. 1) includes the cities of Amambaí, Iguatemi, Jardim, Naviraí, and Tacuru, located in the State of Mato Grosso do Sul, Brazil. Farming is the main economic activity of the region, which is characterized as an area of rural watersheds. The pedology of the study area is composed of orthic Quartzarenic Neosoil (RQo), which is derived from sandstone rock, and of dystrophic Red Latosol (dRL) and eutrophic Red Argisol (PVe), both with a basalt origin.

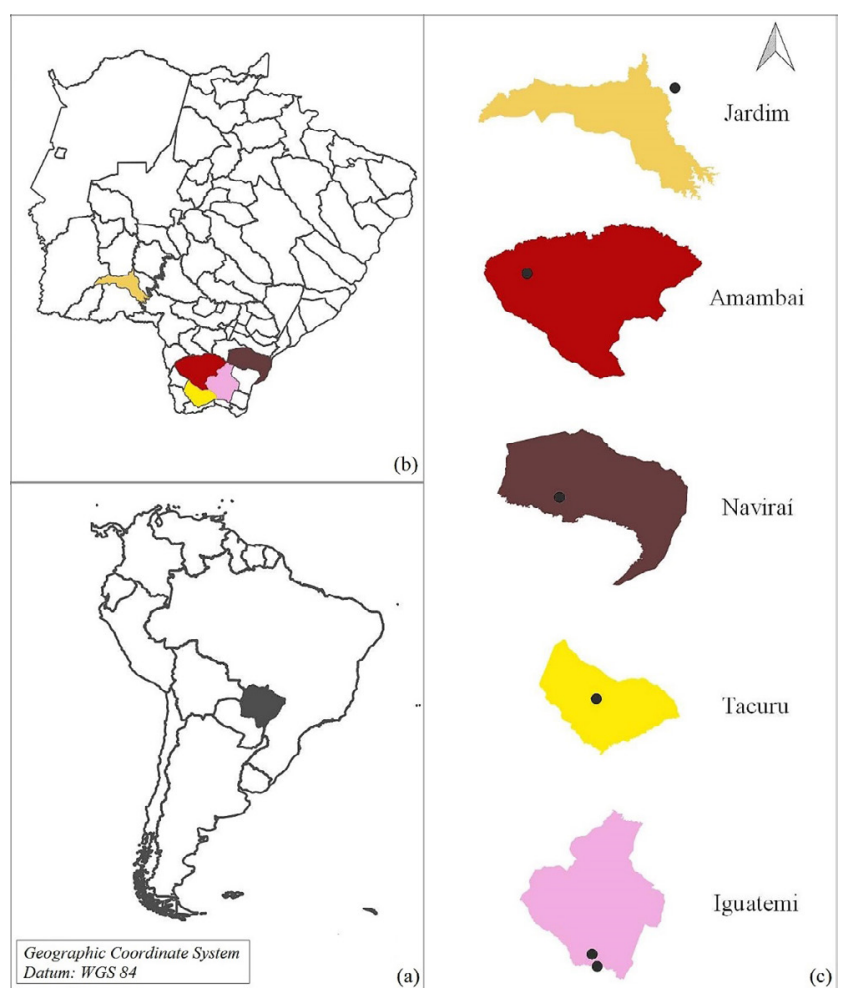

Figure 1 - Studied cities and locations of the measurement stations: a) State of Mato Grosso do Sul in South America, b) Studied cities in State of Mato Grosso do Sul, and c) Measurement stations in the studied cities

Source: Authors.

According to Köppen's climate classification, the prevailing climate in Jardim and Naviraí territory is Aw (Tropical savanna, wet), which is defined as hot and humid. This classification is attributed to regions where the climate is markedly seasonal, with rainfall of more than $250 \mathrm{~mm}$ per month between December and February (Alvares et al., 2013), showing well-defined rainfall periods with an average annual rainfall of around $1,500 \mathrm{~mm}$. The months from November to April are the rainiest, whereas the driest period extends from July to September. The prevailing climate in Amambai, Iguatemi, and Tacuru territory is $\mathrm{Cfa}$ (Humid subtropical climate), a humid temperate climate with hot summers. This classification is attributed to regions where summer and winter seasons are well defined, with an annual average rainfall of between 1,500 and $1,700 \mathrm{~mm}$, which is higher in the summer $(>600 \mathrm{~mm}$ ) but may also occur during the winter $(<200$ $\mathrm{mm})$. The mean air temperature in the warmest month is higher than $22^{\circ} \mathrm{C}$ (Alvares et al. 2013). The territorial area obtained by Instituto Brasileiro de Geografia e Estatística (IBGE), predominant soils, and climate of each city are presented in Table 1.

\begin{tabular}{|l|l|l|l|}
\hline City & $\begin{array}{l}\text { City territory } \\
\text { (IBGE 2016) }\end{array}$ & $\begin{array}{l}\text { Predominant } \\
\text { Soil Class (Santos } \\
\text { et al. 2011) }\end{array}$ & $\begin{array}{l}\text { Predominant } \\
\text { Climate (Alvares } \\
\text { et al. 2013) }\end{array}$ \\
\hline Amambaí & $4.202 \mathrm{~km}^{2}$ & $\begin{array}{l}\text { dystrophic Red } \\
\text { Latosol (LVd27) }\end{array}$ & Cfa and Aw \\
\hline Iguatemi & $2.947 \mathrm{~km}^{2}$ & $\begin{array}{l}\text { orthic } \\
\text { Quartzarenic } \\
\text { Neosoil (RQo24) }\end{array}$ & Cfa \\
\hline Jardim & $2.201 \mathrm{~km}^{2}$ & $\begin{array}{l}\text { eutrophic Red } \\
\text { Argisol (PVe32) }\end{array}$ & Aw \\
\hline Naviraí & $3.193 \mathrm{~km}^{2}$ & $\begin{array}{l}\text { dystrophic Red } \\
\text { Latosol (LVd43) }\end{array}$ & Aw \\
\hline Tacuru & $1.786 \mathrm{~km}^{2}$ & $\begin{array}{l}\text { dystrophic Red } \\
\text { Latosol (LVd26 } \\
\text { e LVd27) }\end{array}$ & Cfa \\
\hline
\end{tabular}

Table 1 - Study area characteristics Source: Authors.

\subsection{Hydrological data}

Dense rain-gauge networks, high temporal-resolution sampling, and long-term data collection are all necessary to capture extreme and infrequent events (Keefer et al., 2016). The hydrological data series used in this study was collected from the Agência Nacional de Águas (ANA) database. In each city, the station with the longest measurement period was selected to be used in the estimation of maximum rainfall (Table 2). Datasets of telemetry station 64725000 , whose operator is Itaipu, were used to obtain the rainfall height in the period that was recorded disaster by heavy rains in the city. The hydrological data were prepared and worked on using an electronic spreadsheet.

\begin{tabular}{|l|l|l|l|l|}
\hline $\begin{array}{l}\text { Station } \\
\text { code }\end{array}$ & City & Latitude & Longitude & $\begin{array}{l}\text { Size of } \\
\text { data series }\end{array}$ \\
\hline 2355000 & Amambaí & $23,10^{\circ} \mathrm{S}$ & $55,24^{\circ} \mathrm{W}$ & 47 years \\
\hline 2354001 & Iguatemi & $23,68^{\circ} \mathrm{S}$ & $54,56^{\circ} \mathrm{W}$ & 47 years \\
\hline 2156001 & Jardim & $21,44^{\circ} \mathrm{S}$ & $56,09^{\circ} \mathrm{W}$ & 51 years \\
\hline 2354000 & Naviraí & $23,06^{\circ} \mathrm{S}$ & $54,19^{\circ} \mathrm{W}$ & 47 years \\
\hline 2355003 & Tacuru & $23,64^{\circ} \mathrm{S}$ & $55,02^{\circ} \mathrm{W}$ & 35 years \\
\hline
\end{tabular}

Table 2 - Stations characteristics. Source: Authors. 


\subsection{Disaster data}

A disaster is characterized as the result of adverse, natural, or human-made adverse events in a vulnerable environment, causing serious disruption to the functioning of a community or society involving extensive human, material, economic, or environmental loss and damage exceeding the region's ability to cope with the problem through its means (BRAZIL, 2012). The Brazilian System of Civil Protection and Defense (SINPDEC) comprises a group of municipalities affected by natural or technological events that trigger damage and losses that characterize a disaster. This information is obtained through the Disaster Information Form (FIDE), which is regulated by Normative Instruction No. 2 from 12/20/2016 (BRAZIL, 2016).

In this study, the starting point of the investigation was the generation of this form, allowing the damage and losses to be measured. The State Coordination of Civil Defense of Mato Grosso do Sul (CEDEC/MS) database has information inserted in the FIDE, as adopted by SINPDEC, by municipalities affected by natural or technological events that triggered damage and losses characterizing a disaster. The dataset contained in the FIDE was used to characterize the susceptibility of the region to the events of maximum precipitation. The losses and damage data recorded in the FIDEs were used to verify which projects were susceptible to collapse when faced with extreme tropical rainfall events and investigate their dimensioning normative criteria.

\subsection{Structural failure risk and return period re-} commended for hydraulic projects

A risk assessment requires a description of the probabilistic properties of the hydrological variables (Renard and Lang, 2007). According to Şen (1999), the risk (R) can be defined as the probability of occurrence of a hydrological variable being greater than the design magnitude at least once over the system's economic life (equation 1).

$$
R=1-(1-1 / T)^{n}
$$

Where $T$ is the return period or recurrence interval in years, $n$ is the number of years of use of the facility or the lifetime of its use, and $\mathrm{R}$ is the risk given in percentage.

The calculated risks are very important in the design of a structure (Tung and Wong 2014), and are commonly used to design and evaluate flood-related hydraulic structures (Salas et al., 2013; Tingsanchali and Karim, 2010). According to the calculated risk for the probable lifetime of a structure, it possible to observed that, for small return periods, the designer assumes a high risk of structural collapse during a natural disaster, such as an extreme rainfall event. Researchers (Tingsanchali and Karim, 2010; Gebregiorgis and Hossain, 2012) have conducted studies in different countries aiming to minimize structural failures. Tingsanchali and Karim (2010) contributed to a comprehensive assessment of flood hazards and risk for the Phrae flood plain of the Yom River basin in northern Thailand. Gebregiorgis and Hossain (2012) conducted a reassessment of the oldest dam in the Tennessee River basin, the Wilson Dam, based on post dam flow data.

Recommendations have been made regarding the use of the return period for hydraulic design and other structures. In Brazil, a recommended standard includes the Manual of DNIT (2010), which contains many recommendations about the return period of hydraulic structures (Table 3).

\begin{tabular}{|l|l|}
\hline Hydraulic Structures & Return Period (years) \\
\hline Surface Drainage & 5 to 10 \\
\hline Subsurface Drainage & 10 \\
\hline Tubular culverts & 15 (as a channel) \\
\cline { 2 - 2 } & 25 (as an orifice) \\
\hline \multirow{2}{*}{ Cellular culverts } & 25 (as a channel) \\
\cline { 2 - 2 } & 50 (as an orifice) \\
\hline Small bridge (Pontilhão) & 50 \\
\hline Bridge & 100 \\
\hline
\end{tabular}

Table 3 - Return period of hydraulic structure for DNIT (2010). Source: DNIT (2010).

There are other recommendations used for dimensioning in Brazil, including DAEE-CETESB (1986) and Naghettini and Horizonte (1999) (Table 4).

\begin{tabular}{|l|l|l|}
\hline $\begin{array}{l}\text { Hydraulic } \\
\text { Structure }\end{array}$ & Characterization & $\begin{array}{l}\text { Return pe- } \\
\text { riod (years) }\end{array}$ \\
\hline Road culverts & Low traffic & 5 to 10 \\
\cline { 2 - 3 } & Intermediate traffic & 10 to 25 \\
\cline { 2 - 3 } & High traffic & 50 to 100 \\
\hline \multirow{3}{*}{ Road bridges } & Secondary road & 10 to 50 \\
\cline { 2 - 3 } & Primary road & 50 to 100 \\
\hline \multirow{5}{*}{ Urban drainage } & $\begin{array}{l}\text { Small cities drai- } \\
\text { nage gallery }\end{array}$ & 2 to 25 \\
\cline { 2 - 3 } & $\begin{array}{l}\text { Major cities drai- } \\
\text { nage gallery }\end{array}$ & 25 to 50 \\
\cline { 2 - 3 } & Channeling stream & 50 to 100 \\
\hline \multirow{2}{*}{ Dike } & Rural area & 2 to 50 \\
\cline { 2 - 3 } & Urban area & 50 to 200 \\
\hline \multirow{2}{*}{ Dams } & No risk of loss of human life & 200 to 1000 \\
\cline { 2 - 3 } & At risk of loss of human life & 10000 \\
\hline
\end{tabular}

Table 4 - Return period for hydraulic structures. Source: Naghettini and Horizonte (1999). 
The Porto (1995) recommendations consider the characteristics of the area to estimate the return period in a project (Table 5).

\begin{tabular}{|l|l|l|}
\hline Work & Occupation area & T (years) \\
\hline Micro drainage & Residential & 2 \\
\cline { 2 - 3 } & Commercial & 5 \\
\cline { 2 - 3 } & Areas with public service buildings & 5 \\
\cline { 2 - 3 } & Airports & $2-5$ \\
\cline { 2 - 3 } & $\begin{array}{l}\text { Commercial areas and } \\
\text { Macfic arteries }\end{array}$ & $5-10$ \\
\hline \multirow{5}{*}{ Macro drainage } & Commercial and residential areas & $50-100$ \\
\cline { 2 - 3 } & Areas of specific importance & 500 \\
\hline
\end{tabular}

Table 5 - Return period for different types of occupation areas.

Source: Porto (1995).

\subsection{Probabilistic analysis}

An estimation of the rainfall for a desired return period, and for different durations, is often required for the design of hydraulic and other types of structures in a region, which can be achieved through a probabilistic approach (Vivekanandan and Mathew, 2010). Thus, theoretical probability distribution models are often applied to obtain an extrapolation of extreme events for high return periods. Yue and Hashino (2007) affirmed that, for an effective plan, design, and management of water resource engineering, such as an urban water supply, hydropower, or irrigation system, data on the precipitation over longer durations, such as annually, seasonally, or monthly, are necessary. To prevent property and human life loss, designs of hydraulic and hydrologic structures are based on extreme rainfall estimates (Kao and Govindaraju, 2007). According to Renard and Lang (2007), the severity of an extreme hydrological event is expressed as the non-exceedance probability, or equivalently, in terms of the return period. Dawdy and Matalas (1964) define the return period as the average interval of time within which the magnitude of the event will be equaled or exceeded once. The inverse of the return period is the exceedance probability. The precipitation levels of the annual series are listed in decreasing order, associating their respective probability of occurrence (equation 2) and the return period (equation 3).

$$
\begin{aligned}
& p=m /(n+1) \\
& T=1 / p
\end{aligned}
$$

Where $p$ is the cumulative probability of an event being matched or exceeded in magnitude, $m$ is the order number, $\mathrm{n}$ is the total number of years considered, and $\mathrm{T}$ is the return period or recurrence interval in years.
According to Salvadori and De Michele (2007), the return period of hydrological events represents a common criterion for sizing a hydraulic engineering project, and provides a simple, yet efficient, means for conducting a risk analysis. In this study, the annual maximum daily rainfall was arranged in decreasing order of magnitude and plotted on a logarithmic scale with their respective return periods. To analyze the maximum precipitation, Gumbel, Log-Normal (LN), LogPearson Type III (LP3), and Normal distribution models have been applied for the return periods.

Applying these distribution models to a set of observations of a hydrological variable requires a simple random sample drawn from a single population (Naghettini and Pinto, 2007). Thus, in order to be able to analyze the frequency of rainfall, initially the independence, homogeneity and stationarity of the data series were verified. The verification was performed using the following non-parametric tests: Wald and Wolfowitz (1943) test to verify independence; Mann and Whitney test (1947) to analyze homogeneity; and Spearman test, described by NERC (1975), to verify stationarity.

The Gumbel distribution (equations. 4 to 6), is used by the United States National Weather Service (NWS) to adjust the extreme values of rainfall height to be used on maps, which relate the rainfall height variation to an affected area (Silva et al. 2003).

$$
\begin{aligned}
& \beta=6^{0,5} \cdot S / \pi \\
& a=(\mu-0,5772 \cdot \beta) \\
& x(T)=\beta-a \cdot \ln (-\ln (1-1 / T))
\end{aligned}
$$

Where $S$ is the standard deviation, $\mu$ is the mean, and $a$ and $\beta$ are the parameters of the Gumbel distribution obtained using the moments method (Naghettini and Pinto 2007).

The function of the Normal distribution (equation 7) can be expressed in a simplified form in equation (8) with a reduced variable ( $\mathrm{z})$, which is associated with a non-exceedance probability of a standard normal distribution (equation 9).

$$
\begin{aligned}
& \mathrm{f}_{\mathrm{x}}(\mathrm{x})=1 / \sqrt{ }\left(2 \pi \sigma_{\mathrm{x}}\right) \exp \left[-1 / 2\left(\left(\mathrm{x}-\mu_{\mathrm{x}}\right) / \sigma_{\mathrm{x}}\right)^{2}\right] \\
& \mathrm{x}=\mu_{\mathrm{x}}+\mathrm{z} \cdot \sigma_{\mathrm{x}} \\
& \mathrm{z}=[(\mathrm{x}-\mu) / \sigma]
\end{aligned}
$$

Where $\mathrm{x}$ is the maximum precipitation for a given probability, and $\sigma$ is the standard deviation of the annual maximum daily precipitation observed.

Among the probability distributions, LN in the equation (10) has been adjusted well for the Brazilian rainfall distribution (Longo et al., 2006). 


$$
\log (x)=\overline{\log (x)}+z \cdot \sigma_{\log x}
$$

Where $\log (\mathrm{x}), \overline{\log (\mathrm{x})}$, and $\sigma_{\log \mathrm{x}}$ are the logarithm, and the average and standard deviation of the logarithms of the annual maximum daily precipitation observed, respectively.

The LP3 distribution has been one of the most frequently used distributions for hydrologic frequency analyses since the recommendations of the Water Resources Council $(1967,1982)$ of the United States regarding its use as the base method (Singh 1998). The LP3 distribution (equation 11) is calculated in data analysis to estimate the maximum precipitation with a determination of the frequency factor $\mathrm{Kp}$ (Table 6), considering the asymmetry coefficient $g$, equation (12).

$$
\begin{aligned}
& \log (x)=\overline{\log (x)}+K_{p} \cdot \sigma_{\log x} \\
& g=\left[n \sum\left(x_{i}-\bar{x}\right)^{3}\right] /\left[(n-1) \cdot(n-2) \cdot \sigma_{\log x}\right]
\end{aligned}
$$

To analyze the adherence of theoretical probability distributions to the data series, it was used the Kolmogorov-Smirnov test (KS) (Massey Jr., 1951), adopting a significance level of $5 \%$.
In this study, due to the fact that the neperian logarithm of the data series presented negative asymmetry coefficient, it was not possible to estimate the KS for the adherence between the empirical distribution and LP3. The Normal, Log-Normal and Gumbel distributions fit all the data series analyzed (Table 8).

After checking the adherence, the expected maximum precipitation for the recommended return periods for the different hydraulic structures for each city was estimated (Table 9). For relatively short return periods, the LP3 and the Normal distribution presented the highest level of estimated precipitation. However, for large periods of return, the maximum precipitation was estimated by the Gumbel and LN distributions.

\begin{tabular}{|l|l|l|l|l|}
\hline $\begin{array}{l}\text { Station } \\
\text { code }\end{array}$ & City & $\begin{array}{l}\text { Independence } \\
\text { test }\end{array}$ & $\begin{array}{l}\text { Homogeneity } \\
\text { test }\end{array}$ & $\begin{array}{l}\text { Stationarity } \\
\text { test }\end{array}$ \\
\hline 2355000 & Amambaí & Independent & Homogeneous & $\begin{array}{l}\text { Shows no } \\
\text { temporal } \\
\text { tendency }\end{array}$ \\
\hline 2354001 & Iguatemi & $\begin{array}{l}\text { Not } \\
\text { independent }\end{array}$ & Homogeneous & $\begin{array}{l}\text { Shows } \\
\text { temporal } \\
\text { tendency }\end{array}$ \\
\hline 2156001 & Jardim & Independent & Homogeneous & $\begin{array}{l}\text { Shows no } \\
\text { temporal } \\
\text { tendency }\end{array}$ \\
\hline 2354000 & Naviraí & Independent & Homogeneous & $\begin{array}{l}\text { Shows no } \\
\text { temporal } \\
\text { tendency }\end{array}$ \\
\hline 2355003 & Tacuru & Independent & Homogeneous & $\begin{array}{l}\text { Shows } \\
\text { temporal } \\
\text { tendency }\end{array}$ \\
\hline
\end{tabular}

Table 7 - Independence, homogeneity and stationarity tests results of each station. Source: Authors.

\begin{tabular}{|l|l|l|l|l|l|}
\hline $\begin{array}{l}\text { Station } \\
\text { code }\end{array}$ & City & $\begin{array}{l}\text { Critical } \\
\text { value }\end{array}$ & $\begin{array}{l}\text { Normal } \\
\text { distri- } \\
\text { bution }\end{array}$ & $\begin{array}{l}\text { Log- } \\
\text { Normal } \\
\text { distri- } \\
\text { bution }\end{array}$ & $\begin{array}{l}\text { Gumbel } \\
\text { distri- } \\
\text { bution }\end{array}$ \\
\hline 2355000 & Amambaí & 0,198 & 0,063 & 0,107 & 0,103 \\
\hline 2354001 & Iguatemi & 0,201 & 0,117 & 0,098 & 0,082 \\
\hline 2156001 & Jardim & 0,207 & 0,097 & 0,080 & 0,068 \\
\hline 2354000 & Naviraí & 0,198 & 0,097 & 0,072 & 0,081 \\
\hline 2355003 & Tacuru & 0,224 & 0,120 & 0,071 & 0,084 \\
\hline
\end{tabular}

Table 8 - Kolmogorov-Smirnov test result of each station.

\begin{tabular}{|c|c|c|c|c|c|c|c|c|c|}
\hline \multirow{2}{*}{$\begin{array}{l}\text { Station } \\
\text { code }\end{array}$} & \multirow[t]{2}{*}{ Distribution } & \multicolumn{8}{|c|}{$\mathbf{T}$ (years) } \\
\hline & & 2 & 5 & 10 & 25 & 50 & 100 & 200 & 1000 \\
\hline \multirow[t]{4}{*}{2355000} & Normal & 85,69 & 106,11 & 116,79 & 128,18 & 135,53 & 142,15 & 148,20 & 160,68 \\
\hline & Log-Normal & 82,12 & 106,05 & 121,22 & 139,79 & 153,27 & 166,51 & 179,62 & 210,01 \\
\hline & Gumbel & 81,70 & 103,15 & 117,35 & 135,29 & 148,60 & 161,81 & 174,98 & 205,47 \\
\hline & Log-Pearson III & 84,62 & 106,50 & 118,24 & 130,71 & 138,66 & 145,67 & 151,93 & 164,30 \\
\hline
\end{tabular}
Source: Authors. empirical distributions (Fig. 2). 


\begin{tabular}{|c|c|c|c|c|c|c|c|c|c|}
\hline \multirow[t]{4}{*}{2354001} & Normal & 93,28 & 116,63 & 128,84 & 141,86 & 150,27 & 157,83 & 164,76 & 179,03 \\
\hline & Log-Normal & 89,44 & 114,54 & 130,34 & 149,61 & 163,54 & 177,18 & 190,65 & 221,76 \\
\hline & Gumbel & 88,72 & 113,24 & 129,48 & 150,00 & 165,21 & 180,32 & 195,37 & 230,24 \\
\hline & Log-Pearson III & 89,77 & 114,65 & 130,02 & 148,46 & 161,60 & 174,31 & 186,73 & 214,91 \\
\hline \multirow[t]{4}{*}{2156001} & Normal & 90,17 & 116,60 & 130,42 & 145,15 & 154,67 & 163,23 & 171,06 & 187,22 \\
\hline & Log-Normal & 84,67 & 115,86 & 136,49 & 162,56 & 182,00 & 201,45 & 221,07 & 267,77 \\
\hline & Gumbel & 85,02 & 112,77 & 131,14 & 154,36 & 171,58 & 188,68 & 205,71 & 245,17 \\
\hline & Log-Pearson III & 88,58 & 116,42 & 131,22 & 146,69 & 156,33 & 164,68 & 171,98 & 185,87 \\
\hline \multirow[t]{4}{*}{2354000} & Normal & 106,56 & 132,13 & 145,49 & 159,75 & 168,95 & 177,24 & 184,82 & 200,44 \\
\hline & Log-Normal & 102,20 & 131,66 & 150,29 & 173,08 & 189,61 & 205,82 & 221,87 & 259,01 \\
\hline & Gumbel & 101,57 & 128,42 & 146,19 & 168,65 & 185,32 & 201,86 & 218,33 & 256,51 \\
\hline & Log-Pearson III & 105,86 & 132,19 & 145,79 & 159,81 & 168,47 & 175,92 & 182,43 & 194,77 \\
\hline \multirow[t]{4}{*}{2355003} & Normal & 96,32 & 117,08 & 127,93 & 139,49 & 146,97 & 153,69 & 159,84 & 172,53 \\
\hline & Log-Normal & 93,24 & 116,21 & 130,38 & 147,41 & 159,57 & 171,37 & 182,93 & 209,28 \\
\hline & Gumbel & 92,27 & 114,07 & 128,49 & 146,72 & 160,25 & 173,67 & 187,05 & 218,03 \\
\hline & Log-Pearson III & 94,27 & 116,50 & 129,36 & 143,99 & 153,95 & 163,24 & 172,01 & 190,86 \\
\hline
\end{tabular}

Table 9 - Expected precipitation for different return periods calculated through theoretical probability distributions for each station. Source: Authors.
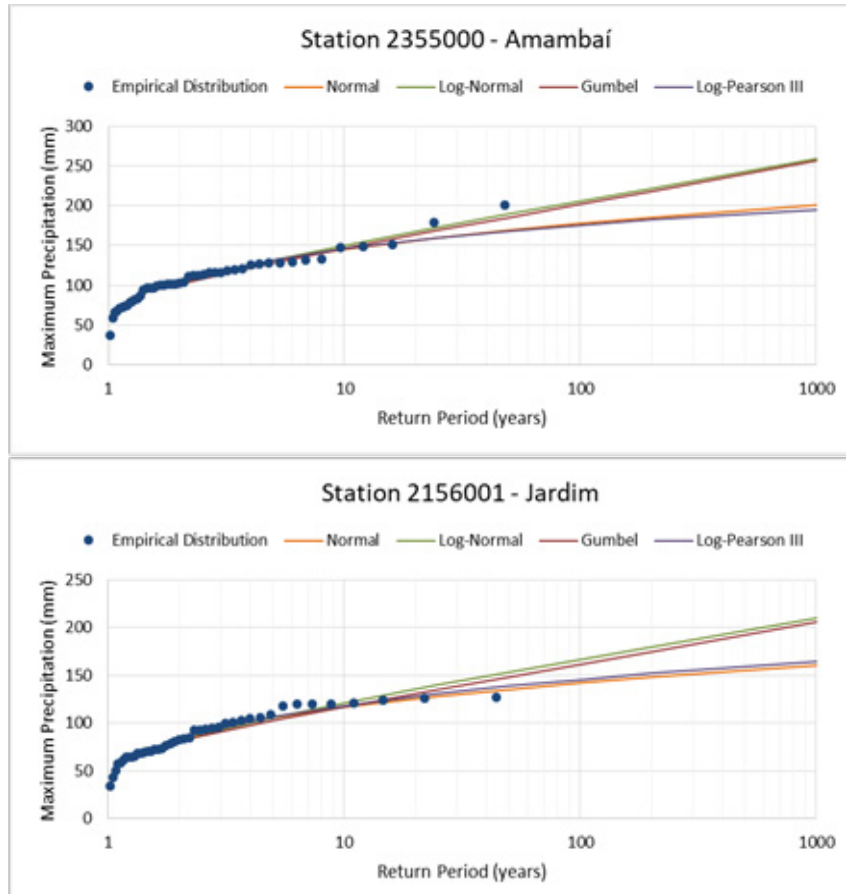

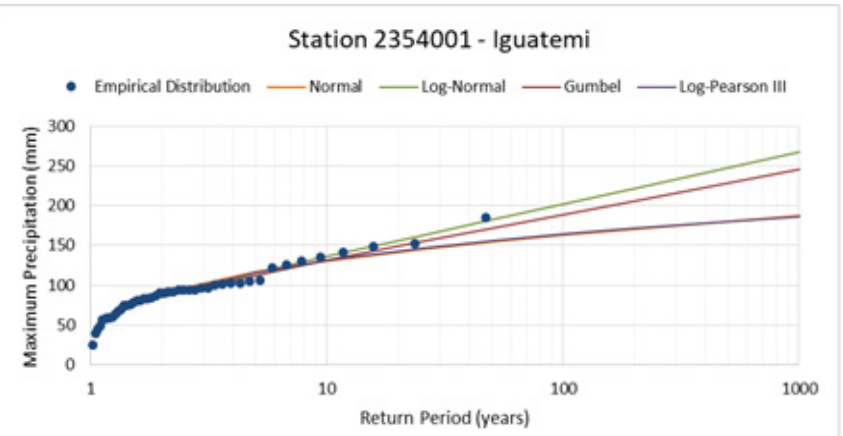

Station 2354000 - Naviraí

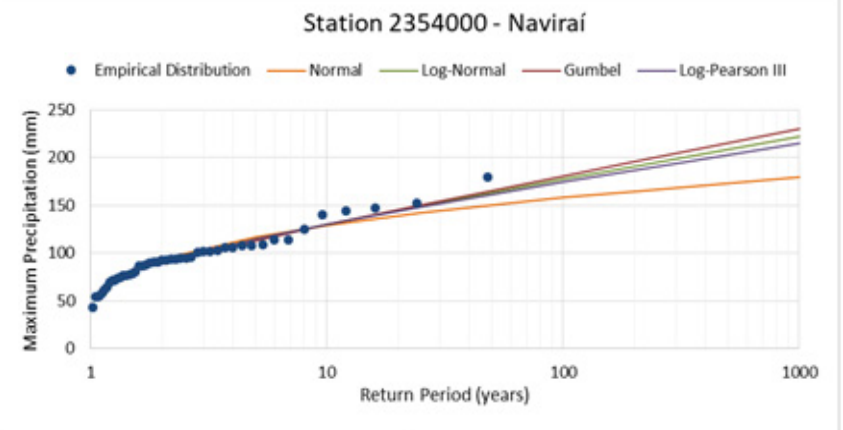

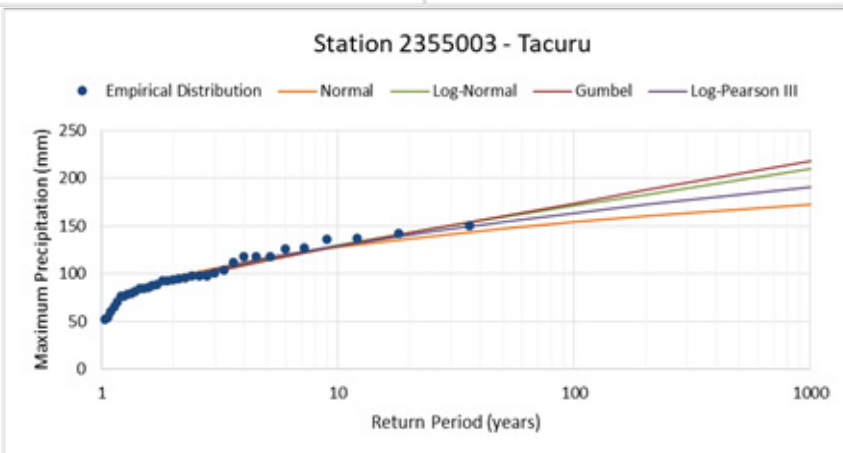

Figure 2 - Adjust Normal, Log-Normal, Gumbel and Log-Pearson III distributions to data series.

Source: Authors. 
Disasters related to heavy rainfall occurred and were recorded in official documents during the last half of November of 2015. The Official Diary of the State of Mato Grosso do Sul, No. 9.059 declared an emergency situation in the study region. The cities of Amambai, Iguatemi, Naviraí and Tacuru experienced a major disaster during a period of 180 days in 2015 (Mato Grosso do Sul, Decree Law "E", № 35, on December 3 2015), which according to information provided in a FIDE (1.3.2.1.4, IN/MI 01/2012), was classified and codified as heavy rainfall. The FIDE reported that urban, rural, commercial, agricultural, and livestock areas were affected by extreme rainfall events. Strong winds and floods caused the destruction of streets, avenues, bridges, flooding of homes, and crop losses. The storm caused damage to some homes, left families homeless, and destroyed roofs, injuring the residents. The cities most affected by heavy precipitation were Amambai, Iguatemi, and Jardim. In Naviraí, the FIDE recorded erosion, ruptures, and damage to the sewage and water networks. The heavy rains caused electric power poles to fall, flooding in some homes, and runoff from streams. In Tacuru, a similar situation occurred, and erosion and landslides were recorded in large portions of the area. The highways were compromised and bridges were damaged, altering the daily lives of the people, preventing the flow of production, compromising local commerce, and making it impossible to provide transportation services and health care, inconveniencing the population and causing significant damage to the city.

At Estrada/Iguatemi Station, code 64725000, operated by Itaipu, $150.6 \mathrm{~mm}$ of rainfall was registered during a $24-\mathrm{h}$ period between 23 and 24 November 2015. This station is located approximately $6.4 \mathrm{~km}$ from the station operated by ANA, where data were obtained from calculations of the maximum return periods. According to the return periods recommended in the standards, the probabilistic distribution models were able to predict the extreme rainfall events of $98.60 \mathrm{~mm}$ for Amambai and $81.20 \mathrm{~mm}$ for Jardim.

All the distributions models were able to predict the extreme event of $140 \mathrm{~mm}$ occurred in Navirai for 25 years of the return period. Gumbel and LN distribution models were able to predict the extreme rainfall events of 150.6 $\mathrm{mm}$ in Iguatemi for 25 years of return periods, and Normal and LP3 for 50 years of return period. Thus, the probabilistic distribution models tested were not able to predict the extreme rainfall events that occurred in the Tacuru region $(185.3 \mathrm{~mm})$ during the recommended return periods of the standards. Furthermore, the probability models were able to predict the occurrence of intense rains in the cities of
Tacuru only when considering a high return period. For a return period of over 200 years, the Gumbel distribution estimated the extreme precipitation that occurred in Tacuru. The precipitation was estimated for a T equal to 1,000 years when using LP3 and LN. Among the analyzed models, the Normal distribution proved to be the least efficient.

According to Koutsoyiannis (2004), the Gumbel distribution has been the prevailing model for rainfall extremes despite the fact that it results in the highest possible risk for engineering structures. Besides, the author shown that hydrological records of typical length (some decades) may display a distorted picture of the actual distribution, suggesting that the Gumbel distribution is an appropriate model for rainfall extremes while it is not.

The results obtained in this work illustrate that even the models being able to predict the precipitations occurred for short return periods, were not sufficient to avoid the occurrence of damage to the structures. Probabilistic distribution models were able to predict the extreme rainfall of $98.60 \mathrm{~mm}$ for Amambai and 81.20 $\mathrm{mm}$ for Jardim, for the recommended return periods. In the cities of Amambai and Jardim, the return period suggested by the manuals for sizing damaged structures predicted the maximum rainfall, but was not sufficient to prevent damage to structures as recorded in the FIDEs of these cities. The return periods suggested by DNIT (2010) failed to predict rainfall that caused damage to manholes and urban drainage systems in the cities of Iguatemi and Naviraí, yet predicted maximum precipitation for bridges, but was unsuccessful in preventing damage to structures. For the city of Tacuru, the design recommendations were unable to predict precipitation that caused damage to bridges, culverts and urban drainage. These intense precipitations could not be estimated, requiring alternative measures that offer greater protection to the population.

This fact indicates the importance of inserting new parameters for the structural dimensions because increasing only the time of return makes the projects too expensive. Thus, alternative measures that offer adequate protection to the population are necessary. In the case of China, which has more than 5,000 years of experience in flood management policy, a form was implemented to prevent such future events using structural solutions allied with non-structural techniques, including changes in land use, welfare, removal in vulnerable areas, and environmental protection (Luo et al., 2015). Countries like South Africa have experienced similar situations, in which most of the methods used, developed between 1960 to 
1970 (HRU, 1972), are already out-dated and need to be updated to meet the current conditions for estimating projected flooding (Görgens, 2007; Smithers et al., 2015).

The lifetime use of a manhole according to Tung et al. (2006) is 35 years. In this study it was verified that even damaged projects were dimensioned according to the recommendations of the NBR 15575 (2013), considering a lifetime use of 50 years, which is common for structural works, and the risk of failure was assumed to be high. Furthermore, the lower the return period applied, the higher the risk that is assumed. In addition, the return periods suggested through the Brazilian regulations have not considered the frequent occurrence of intense precipitation in the face of global climate change.

According to DNIT (2010), the risk assessment already includes the occurrence of extreme situations since the return period of large structures is great. However, external situations can generate structural faults interfering in the return period of the structure. In the bridges, assuming a correct dimensioning, the main interference is the flood, due to the erosive action around the pillars, which causes the wear of the structure. According to Selvakumaran et al. (2018) the most common cause of bridge collapse is due to the removal of ground material at its piers during flooding, some failures causing loss of life and most resulting in significant transport disruption and economic loss.

In other countries that use the return period as the index in their classes, the return period is based primarily on historical data or previous practical applications, or on a comparison of statistical tests. According to Ren et al. (2017), in China and Russia, a Pearson Type III distribution is used, whereas, in Canada and India, a Logarithmic and Pearson Type III distribution is applied.

DAEE-CETESB (1986) and Naghettini and Horizonte (1999) recommend that the return period varies from 5 years for a culvert construction to 10,000 years for major dam construction. Gebregiorgis and Hossain (2012) affirmed that there are different guidelines for selecting the return period or flooding of hydraulic structures in the design used by different agencies.

According to Ren et al. (2017), in the United States, a frequency analysis was adopted for reservoir projects until 1930, and from 1938 the hydrometeorology method began being used. The United States Army Corps of Engineers (USACE) proposed a risk classification during the 1970s. The most common methods applied are flood frequency analysis and hydrometeorology. In South Africa, a drainage manual (SANRAL 2007) is used. In this manual, the methods used to estimate the project floods are based on empirical, deterministic, and probabilistic approaches. When the records are inadequate, or there is simply no flow data available at the site of interest, the unit hydrograph, Rational Method, and SCS methods, which are based on rainfall-flow events for flood estimation in South Africa, are recommended (Smithers, 2012). However, Van der Spuy and Rademeyer (2010) affirmed that the search continues in South Africa for a universally applicable design flood estimation method. Such searches include a rational method based on probability, called a Flood Standard Design (SDF), developed by Alexander (2001); the Joint Peak-Volume (JPV) developed by Görgens (2007); and the Regional Estimation of Extreme Flood Peaks by Selective Statistical Analysis (REFSSA), developed by Nortje (2010).

\section{CONCLUSIONS}

Tropical climate regions are characterized for their heavy rainfall events during the summer, and in recent years, as a result of climate change, such events are becoming recurrent.

The cities selected for the study area were affected by heavy rainfall in November 2015 and experienced a disaster that lasted for a period of 180 days. The rainfall event caused significant damage and losses, and different types of structures were affected, mainly hydraulic.

In this paper, we discussed whether the probabilistic distribution models are adequate for predicting extreme rainfall events for regions with climate characteristics to the study area. Therefore, we concluded that the Gumbel, LN, LP3, and normal probabilistic distribution models are not recommended to design the infrastructure found in the studied cities.

The probability models were able to predict the occurrence of extreme rainfall in the cities of Iguatemi and Tacuru only when considering a high return period.

Statistical analysis showed that the data series of the city of Iguatemi and Tacuru showed a temporal trend. The fact that the series are not stationary demonstrates the scarcity of extensive data sets available.

\section{ACKNOWLEDGMENTS}

The authors are grateful to the Coordenação de Aperfeiçoamento de Pessoal de Nível Superior CAPES, to the Conselho Nacional de Desenvolvimento Científico e Tecnológico - CNPq, to the Programa de Apoio à Pós-graduação - PROAP and to the Federal University of Mato Grosso do Sul - UFMS for their support in the development of this work. 


\section{REFERENCES}

AGÊNCIA NACIONAL DE ÁGUAS (ANA). Available in: http://www.snirh.gov.br/hidroweb/. Accessed in: August, 12, 2017.

ALEXANDER, W. J. R. Flood risk reduction measures: Incorporating flood hydrology for Southern Africa. Department of Civil and Biosystems Engineering, University of Pretoria, Pretoria, 2001.

ALVARES, C. A.; STAPE, J. L.; SENTELHAS, P. C.; GONÇALVES, J. D. M.; SPAROVEK, G. Köppen's climate classification map for Brazil. Meteorologische Zeitschrift, v. 22, n. 6, p. 711-728, 2013. DOI: 10.1127/0941-2948/2013/0507

BABAR, S.; RAMESH, H. Analysis of extreme rainfall events over Nethravathi basin. ISH Journal of Hydraulic Engineering, v. 20, n. 2, p. 212-221, 2014. DOI: 10.1080/09715010.2013.872353

BAPTISTA, M. B.; DE OLIVEIRA NASCIMENTO, N.; BARRAUD, S. Técnicas compensatórias em drenagem urbana. ABRH, 2011.

BRAZIL. Instrução Normativa n. 001 , de agosto de 2012. Estabelece procedimentos e critérios para a decretação de situação de emergência ou estado de calamidade pública pelos Municípios, Estados e pelo Distrito Federal, e para o reconhecimento federal das situações de anormalidade decretadas pelos entes federativos e dá outras providências. Diário Oficial da União, Brasília, DF: Ministério da Integração Nacional. Brazil. (2012).

BRAZIL. Instrução Normativa No 02, de 20 de dezembro de 2016. Estabelece procedimentos e critérios para a decretação de situação de emergência ou estado de calamidade pública pelos Municípios, Estados e pelo Distrito Federal, e para o reconhecimento federal das situações de anormalidade decretadas pelos entes federativos e dá outras providências. Diário Oficial da União, Brasília, DF: Ministério Da Integração Nacional. Brazil. (2016)

DAVE, H.; ME, J.. Characteristics of intense rainfall over Gujarat State (India) based on percentile criteria. Hydrological Sciences Journal, v. 62, n. 12, p. 20352048, 2017. DOI: 10.1080/02626667.2017.1357818

DAWDY, D. R.; MATALAS, N. C. Statistical and probability analysis of hydrologic data, part III: Analysis of variance, covariance and time series. Handbook of applied hydrology, a compendium of water-resources technology, p. 8.68-8.90, 1964.

DEPARTAMENTO DE ÁGUAS E ENERGIA ELÉTRICA - COMPANHIA DE TECNOLOGIA DE SANEAMENTO
AMBIENTAL (DAEE-CETESB). DAEE-CETESB - Drenagem urbana: Manual de projeto. São Paulo: DAEE/CETESB. (1986)

DEPARTAMENTO NACIONAL DE INFRAESTRUTURA DE TRANSPORTES (DNIT). Diretoria Executiva. Instituto de Pesquisas Rodoviárias. Diretrizes básicas para elaboração de estudos e projetos rodoviários: instruções para acompanhamento e análise. Rio de Janeiro: IPR. (2010) GEBREGIORGIS, A. S.; HOSSAIN, F. Hydrological risk assessment of old dams: Case study on Wilson Dam of Tennessee River Basin. Journal of Hydrologic Engineering, v. 17, n. 1, p. 201-212, 2012. DOI: 10.1061/ (ASCE)HE.1943-5584.0000410

GÖRGENS, A. Joint Peak-Volume (JPV) Design Flood Hydrographs for South Africa: WRC Report No 1420/3/07. 2007.

HAJANI, E.; RAHMAN, A.; ISHAK, E. Trends in extreme rainfall in the state of New South Wales, Australia. Hydrological Sciences Journal, v. 62, n. 13, p. 2160 2174,2017 . DOI : 10.1080/02626667.2017.1368520 HYDROLOGICAL RESEARCH UNIT (HRU). Design flood determination in South Africa. Report No. 1/72. Hydrological Research Unit, Johannesburg: Department of Civil Engineering, University of the Witwatersrand. (1972).

INSTITUTO BRASILEIRO DE GEOGRAFIA E ESTATÍSTICA (IBGE) Informações dos estados brasileiros. Available: https://www.ibge.gov.br/. (2016) Acess in: may 122017. INTERGOVERNMENTAL PANEL ON CLIMATE CHANGE (IPCC). Managing the risks of extreme events and disasters to advance climate change adaptation, A Special Report of Working Groups I and II of the Intergovernmental Panel on Climate Change, New York: Cambridge University Press. (2012)

JAIN, S. K, KUMAR, V. Trend analysis of rainfall and temperature data for India. Current Science, 37-49. (2012) KAO, S. C.; GOVINDARAJU, R. S. A bivariate frequency analysis of extreme rainfall with implications for design. Journal of Geophysical Research: Atmospheres, v. 112, n. D13, 2007. DOI: 10.1029/2007JD008522 KEEFER, T. O.; RENARD, K. G.; GOODRICH, D. C.; HEILMAN, P.; UNKRICH, C. Quantifying extreme rainfall events and their hydrologic response in southeastern Arizona. Journal of Hydrologic Engineering v. 21, n. 1, p. 04015054, 2016. DOI: 10.1061/(ASCE) HE.1943-5584.0001270

KITE, G. W. Frequency and risk analyses in hydrology. Water Resources Publications, Fort Collins, Colorado. (1977). 
KOUTSOYIANNIS, D. Statistics of extremes and estimation of extreme rainfall: II. Empirical investigation of long rainfall records/Statistiques de valeurs extrêmes et estimation de précipitations extrêmes: Il. Recherche empirique sur de longues séries de précipitations. Hydrological Sciences Journal, v. 49, n. 4, 2004.

KYOUNG, M. S.; KIM, H. S.; SIVAKUMAR, B.; SINGH, V. P.; AHN, K. S. Dynamic characteristics of monthly rainfall in the Korean Peninsula under climate change. Stochastic Environmental Research and Risk Assessment, v. 25, n. 4, p. 613-625, 2011. DOI: 10.1007/ s00477-010-0425-9

LONGO, A. J.; SAMPAIO, S. C.; SUSZEK, M. Equações de chuvas intensas e precipitação provável para o município de Cascavel-Paraná. Varia Scientia, v. 6, n. 11, p. 119-127, 2006.

LUO, P.; HE, B.; TAKARA, K.; XIONG, Y. E.; NOVER, D.; DUAN, W.; FUKUSHI, K. Historical assessment of Chinese and Japanese flood management policies and implications for managing future floods. Environmental Science \& Policy, v. 48, p. 265-277, 2015. DOI: 10.1016/j. envsci.2014.12.015

MANN, H. B.; WHITNEY, D. R. On a test of whether one of two random variables is stochastically larger than the other. The annals of mathematical statistics, p. 5060, 1947. DOI: https://www.jstor.org/stable/2236101

MASSEY JR, Frank J. The Kolmogorov-Smirnov test for goodness of fit. Journal of the American statistical Association, v. 46, n. 253, p. 68-78, 1951. DOI: https:// doi.org/10.1080/01621459.1951.10500769

MATO GROSSO DO SUL. Decreto "E", No 35, de 3 de dezembro de 2015, Diário Oficial n. 9.059, de 4 de dezembro de 2015. Mato Grosso do Sul. (2015)

MUHAMMAD, N. S.; JULIEN, P. Y.; SALAS, J. D. Probability structure and return period of multiday monsoon rainfall. Journal of Hydrologic Engineering, v. 21 , n. 1, p. 04015048 , 2016. DOI: 10.1061/(ASCE) HE.1943-5584.0001253

NAGHETTINI, M; HORIZONTE B. Engenharia de recursos hídricos. Belo Horizonte: UFMG. (1999).

NAGHETTINI, M; PINTO É. J. D. A. Hidrologia estatística. Belo Horizonte: CPRM (2007).

NBR15575: Edificações Habitacionais - Desempenho. Parte 1: Requisitos gerais. Rio de Janeiro: ABNT. (2013). NERC - Natural Environment Research Council. Flood Studies Report. Vol. 1, pp. 81-97, London, U.K. (1975). NORTJE, J. H. Estimation of extreme flood peaks by selective statistical analyses of relevant flood peak data within similar hydrological regions. Journal of the
South African Institution of Civil Engineering, v. 52, n. 2, p. 48-57, 2010.

PORTO, R. L. L. Escoamento superficial direto. In: Tucci, C., Porto, Rubem La Laina \& Barros, Mario. Drenagem Urbana. Porto Alegre: ABRH/Editora da Universidade/ UFRGS. (1995)

RAHMANI, V.; HUTCHINSON, S. L.; HUTCHINSON, J. S.; ANANDHI, A. Extreme daily rainfall event distribution patterns in Kansas. Journal of Hydrologic Engineering, v. 19, n. 4, p. 707-716, 2014. DOI:10.1061/(ASCE) HE.1943-5584.0000839

REN, M.; HE, X.; KAN, G.; WANG, F.; ZHANG, H.; LI, H.; CAO, D.; WANG, H.; SUN, D.; JIANG, X.; WANG, G.; ZHANG, Z. A comparison of flood control standards for reservoir engineering for different countries. Water, v. 9, n. 3, p. 152, 2017. DOI: 10.3390/w9030152.

RENARD, B.; LANG, M. Use of a Gaussian copula for multivariate extreme value analysis: Some case studies in hydrology. Advances in Water Resources, v. 30, n. 4, p. 897-912, 2007. DOI: 10.1016/j.advwatres.2006.08.001 SALAS, J. D.; HEO, J. H.; LEE, D. J.; BURLANDO, P. Quantifying the uncertainty of return period and risk in hydrologic design. Journal of Hydrologic Engineering, v. 18, n. 5, p. 518-526, 2013. DOI: 10.1061/ (ASCE)HE.1943-5584.0000613

SALVADORI, G.; DE MICHELE, C. On the use of copulas in hydrology: theory and practice. Journal of Hydrologic Engineering, v. 12, n. 4, p. 369-380, 2007. DOI: 10.1061/ (ASCE)1084-0699 (2007)12:4(369)

SANRAL Drainage Manual. Pretoria: SANRAL. (2007). SANTOS, H. D.; CARVALHO JÚNIOR, W.; DART, R; ÁGLIO, M.; SOUSA, J.; PARES, J.; FONTANA, A.; MARTINS, A. L.; OLIVEIRA, A. O novo mapa de solos do Brasil — legenda atualizada. Rio de Janeiro, Brasil: Embrapa Solos. (2011)

ŞEN, Z. Simple risk calculations in dependent hydrological series. Hydrological sciences journal, v. 44, n. 6, p. 871-878, 1999. DOI: 10.1080/02626669909492286

SELVAKUMARAN, S.; PLANK, S.; GEIß, C.; ROSSI, C.; MIDDLETON, $C$. Remote monitoring to predict bridge scour failure using Interferometric Synthetic Aperture Radar (InSAR) stacking techniques. International journal of applied earth observation and geoinformation, v. 73, p. 463-470, 2018.

SILVA, D. D.; PEREIRA, S. B.; PRUSKI, F. F.; GOMES FILHO, R. R.; LANA, A. M. Q.; BAENA, L. G. N. Equações de intensidade-duração-freqüência da precipitação pluvial para o estado de Tocantins. Engenharia na Agricultura, Viçosa, v. 11, n. 1/4, p. 7-14, 2003. 
SINGH, V. P. Log-pearson type III distribution. In: Entropy-based parameter estimation in hydrology. Springer, Dordrecht, 1998. p. 252-274. DOI: 10.1007/978-94-017-1431-0_15

SINPDEC - Sistema Nacional de Proteção e Defesa Civil - Available in http://www.mi.gov.br/defesa-civil/s2id. Accessed in May 162017.

SMITHERS, J. C. Methods for design flood estimation in South Africa. Water SA, v. 38, n. 4, p. 633-646, 2012. DOI: 10.4314/wsa.v38i4.19

SMITHERS, J. C.; STREATFIELD, J.; GRAY, R. P.; OAKES, E. G. M. Performance of regional flood frequency analysis methods in KwaZulu-Natal, South Africa. Water SA, v. 41, n. 3, p. 390-397, 2015. DOI: 10.4314/wsa.v41i3.11

TINGSANCHALI, T.; KARIM, F. Flood-hazard assessment and risk-based zoning of a tropical flood plain: case study of the Yom River, Thailand. Hydrological Sciences Journal-Journal des Sciences Hydrologiques, v. 55, n. 2, p. 145-161, 2010. DOI: 10.1080/02626660903545987

TUNG, Y.; WONG, C. Assessment of design rainfall uncertainty for hydrologic engineering applications in Hong Kong. Stochastic environmental research and risk assessment, v. 28, n. 3, p. 583-592, 2014. DOI: 10.1007/s00477-013-0774-2 engineering reliability assessment and risk analysis. 2006.

VAN DER SPUY, D.; RADEMEYER, P. F. Flood frequency estimation methods as applied in the Department of Water Affairs. Department of Water Affairs, Pretoria, 2010.

VIVEKANANDAN, N.; MATHEW, F. T. Probabilistic modelling of annual d-day maximum rainfall. ISH Journal of Hydraulic Engineering, v. 16, n. sup1, p. 122-133, 2010. DOI: 10.1080/09715010.2010.10515021

WALD, A.; WOLFOWITZ, J. An exact test for randomness in the non-parametric case based on serial correlation. The Annals of Mathematical Statistics, v. 14, n. 4, p. 378-388, 1943.

WATER RESOURCES COUNCIL. A uniform technique for determining flood flow frequencies. Bulletin No. 15, 15 pp., Washington, D.C. (1967).

WATER RESOURCES COUNCIL. Guidelines for determining flood flow frequency. Bulletin $17 \mathrm{~B}$, Hydrology Subcommittee, Interagency Advisory Committee on Water Data, Washington, D.C. (1982).

YANG, T.; SHAO, Q.; HAO, Z. C.; CHEN, X.; ZHANG, Z.; XU, C. Y.; SUN, L. Regional frequency analysis and spatio-temporal pattern characterization of rainfall extremes

in the Pearl River Basin, China. Journal of Hydrology, v. 380, n. 3-4, p. 386-405, 2010. DOI: 10.1016/j. jhydrol.2009.11.013

YUE, S.; HASHINO, M. Probability distribution of annual, seasonal and monthly precipitation in Japan. Hydrological sciences journal, v. 52, n. 5, p. 863-877, 2007. DOI: $10.1623 /$ hysj.52.5.863 


\section{AUTORES}

ORCID: https://orcid.org/0000-0002-0956-7156

ANA CLARA COSTA OLIVEIRA | UFMS | Av. Costa e Silva, s/n | Cidade Universitária | 79070-900 | Campo Grande | MS | Brasil | e-mail: anaclara.c.oliveira@gmail.com

ORCID: https://orcid.org/0000-0003-3821-3776

ALESKA KAUFMANN ALMEIDA, M.Sc. | Saneamento Ambiental e Recursos Hídricos | UFMS | Av. Costa e Silva, s/no | Cidade Universitária | 79070-900 | Campo Grande | MS | Brasil | e-mail: aleska.kaufmann@gmail.com

ORCID: https://orcid.org/0000-0003-0962-7777

JOSÉ ANTONIO GUARIENTI | UFMS | Av. Costa e Silva, s/n | Cidade Universitária | 79070-900 | Campo Grande | MS | Brasil | e-mail: jose.guarienti@gmail.com

ORCID: https://orcid.org/0000-0002-8447-6385

CLEYLSE ANDREIA SOUZA LIMA, M.Sc. | Saneamento Ambiental e Recursos Hídricos | UFMS | Av. Costa e Silva, s/no | Cidade Universitária | 79070-900 | Campo Grande | MS | Brasil | e-mail: cleylselima@gmail.com

ORCID: https://orcid.org/0000-0002-1616-4718

LÍNIKA VICENTE FERREIRA DE ALMEIDA, M.Sc. | Saneamento Ambiental e Recursos Hídricos | UFMS | Av. Costa e Silva, s/ n | Cidade Universitária | 79070-900 | Campo Grande | MS | Brasil | e-mail: linika_almeida@hotmail.com

ORCID: https://orcid.org/0000-0003-0540-5456

ROBERT SCHIAVETO DE SOUZA, Dr. | Engenharia Hidráulica e Saneamento | UFMS | Av. Costa e Silva, s/no | Cidade Universitária | 79070-900 | Campo Grande | MS | Brasil | e-mail: robert.souza@ufms.br

ORCID: https://orcid.org/0000-0002-8609-2991

ISABEL KAUFMANN DE ALMEIDA, Dra. | Saneamento Ambiental e Recursos Hídricos | UFMS | Av. Costa e Silva, s/n | Cidade Universitária | 79070-900 | Campo Grande | MS | Brasil | e-mail: isabel.almeida@ufms.br

\section{COMO CITAR ESTE ARTIGO}

OLIVEIRA, Ana Clara Costa; ALMEIDA, Aleska Kaufmann; GUARIENTI, José Antonio; LIMA, Cleyse Andreia Souza; ALMEIDA, Línika Vicente Ferreira de; SOUZA, Robert Schiaveto de; ALMEIDA, Isabel Kaufmann de. Extreme Precipitation Events And Associated Risk Of Failure In Hydraulic Projects In The State Of Mato Grosso Do Sul, Brazil. MIX Sustentável, [S.I.], v. 7, n. 2, p. 147-160, abr. 2021. ISSN 24473073. Disponível em:<http://www. nexos.ufsc.br/index.php/mixsustentavel>. Acesso em: dia mês. ano. doi:https://doi.org/10.29183/2447-3073. MIX2021.v7.n2.147-160.

DATA DE ENVIO: $13 / 10 / 2020$

DATA DE ACEITE: 11/03/2021 
